\title{
KONSEPSI DAN APLIKASI PIDANA MATI DALAM PERADILAN DI INDONESIA ${ }^{1}$
}

\section{Oleh :}

\author{
I Made Pasek Budiawan ${ }^{2}$
}

\begin{abstract}
Imposition of the death penalty by the judge in the criminal justice process Indonesia still remains a debate among groups that agread with the group that oppose it. But in some laws for special crimes such as terrorism, corruption, narcotics, psychotropic substances, and a human rights capital punishment is still regulated, as well as of the criminal code and the concept of the criminal code by 2015 capital punishment is still based. The existence of the group that did not agree with the conception and application of this dying, argued that human life bussiness, my God, not the man to lift the perspective of the scientific criminal law that a death penalty still exists in all criminal acts by perpetrators of crimes with widespread impact as well as detrimental to the wider community the research for criminal santions was important to examine the existence of the norms of law as a basic for corrector by maximum capital punishment in Indonesia.
\end{abstract}

Keywods : capital punishment, concepts, applications

\begin{abstract}
Abstrak
Penjatuhan pidana mati oleh hakim dalam proses peradilan pidana Indonesia masih tetap menjadi perdebatan antara kelompok yang setuju dengan kelompok yang menentangnya. Namun dalam beberapa undang-undang tindak pidana khusus seperti terorisme, korupsi, narkotika, psikotropika dan peradilan hak asasi manusia pidana mati masih diatur, begitu juga KUHP dan konsep KUHP tahun 2015 pidana mati masih tetap dicanangkan. Adanya kelompok yang tidak setuju dengan konsepsi dan aplikasi pidana mati ini berdalih bahwa nyawa manusia menjadi urusan Tuhan, bukan menjadi kewenangan manusia untuk mencabutnya. Perspektif keilmuan hukum pidana bahwa pidana mati masih eksis untuk diberlakukan sepanjang tindak pidana yang dilakukan pelaku menyangkut kejahatan luar biasa dengan dampak luas serta merugikan masyarakat luas. Penelitian terhadap sanksi pidana mati penting dilakukan guna meneliti keberadaan norma hukum sebagai dasar pembenar dijatuhkannya pidana mati ini di Indonesia.
\end{abstract}

Kata kunci : pidana mati, konsep, aplikasinya

1 Artikel ini merupakan karya ilmiah mahasiswa pada Program Studi Magister (S2) Ilmu Hukum Program Pascasarjana Universitas Udayana serta mengucapkan terimakasih kepada Dr. I Gede Artha, SH.,MH dan Dr. I Dewa Made Suartha, SH.,MH selaku pembimbing tesis

2 Mahasiswa magister ilmu hukum Universitas Udayana, Denpasar, Bali, email: mpb.isme@gmail. com 


\section{PENDAHULUAN}

Fenomena penjatuhan pidana mati bagi Indonesia masih tetap menjadi dua kelompok pro dan kontra. Kelompok retensionis atau yang setuju masih mempertahankan tetap diterapkannya pidana mati dengan argumen dan dasar progresifitas kriminal dengan modus operandi serta klasifikasi kejahatan extra ordinary crimes. Sedangkan kelompok anti pidana mati (kelompok abolisionis) dengan dalih serta dasar alasan filofofis - teologis kemanusiaan dengan dasar berlindung dibalik justifikasi Hak Asasi Manusia (HAM).

Bentuk kejahatan tindak pidana umum di Indonesia yang hingga kini paling banyak masih terdakwa nya dituntut dengan pidana mati adalah kasus - kasus pembunuhan berencana (Pasal 340 KUHP) dengan perbuatannya didahului, diikuti serta disertai kekerasan (sesuai pemenuhan unsur Pasal 89 KUHP), atau tindak pidana yang menyertainya seperti modus perampokan, penganiayaan berat, mutilasi, pemerkosaan dan sebagainya.

Beda pula halnya perkembangan kejahatan yang dilakukan dengan memadukan teknis - teknis memanfaatkan arus globalisasi perkembangan ilmu pengetahuan dan teknologi canggih seperti arus kemajuan informasi dan teknologi modus demikian berkorelasi sebagai pendukung sarana kejahatan inkonvensional muncul subur dan dipakai oleh pelaku tindak pidana dengan kualifikasi jenis kejahatan baru bersifat khusus yang perlu pembuktian bagi penegak hukum untuk membuktikannya. Bentuk kejahatan tergolong kejahatan sangat luar biasa (extra ordinary crime) bahkan tergolong sebagai kualifikasi kejahatan kemanusiaan berat (crime against humanity) serta dilakukan secara terselubung (hidden crimes).

Bentuk kejahatan yang tergolong kriteria sangat luar biasa (extra ordinary crime) serta memerlukan penanganan secara extra ordinary efforts seperti trio tindak pidana paling menonjol saat ini adalah tindak pidana narkotika, tidak pidana terorisme dan tindak pidana korupsi. Tampaknya pelaku-pelaku (dader) dari tindak pidana ketiga bentuk diatas adalah layak untuk dipidana mati. Secara factual fenomena penjatuhan pidana mati di Indonesia bagi pelaku narkoba dan terorisme sudah berjalan tanpa hambatan berarti. Kecuali terhadap terdakwa tindak pidana korupsi Indonesia belum menerapkannya, walaupun pengaturannya telah tersedia dalam produk legislasinya, (tersurat dalam Pasal 2 Undang - Undang Nomor 31 Tahun 1999 jo Undang - Undang Nomor 20 Tahun 2001 tentang Pemberantasan Tindak Pidana Korupsi).

Pencanangan dan penerapan sanksi pidana mati bagi pelaku tidak pidana sangat luar biasa dalam berbagai peraturan perundang-udangan pidana 
khusus memakai dasar pembenar penuh kehati-hatian. Pelaksanaan pidana mati masih tetap merupakan anasir dilematis. Eksekusi pidana mati akan dihadapkan pada pilihan hukum antara berbuat atau tidak berbuat, tetap merupakan kebijakan (discretionary power). Karena menurut suatu kebijakan, berbuat atau tidak berbuat tetap merupakan kebijakan (do or not to do is a policy), demikian pernyataan Thommas R. Dye Dalam arti kebutuhan hukum pidana adalah guna melindungi kepentingan masyarakat secara luas dari gangguan kejahatan. Fungsi hukum pidana yang utama (primum remidium) adalah memberantas kejahatan, namun tetap mengedepankan fungsi asas ultimum remidium tersebut. Di pihak lain tetap pula menghormati hak paling prinsip yang dimiliki tiap orang sebagai insan manusia bahwa sejak dalam kandungan sampai lahir dan berkembang hak untuk hidup dan kehidupannya tetap dilindungi hukum, hal demikian sesuai esensi lahirnya generasi Hak Asasi Manusia (HAM) generasi I tersebut.

Hampir semua agama menyiratkan filosofi hidup dan takdir yang percaya bahwa kelahiran, kematian, rezeki dan jodoh penentunya adalah pada Tuhan selaku sang pencipta-Nya. Terutama anasir kematian yang tidakmenjadikehendakNya (penjatuhan perspektif teologis - filosofis tetap menjadi kewenanganNya, hal demikian dijadikan dasar bagi kelompok abolisionis (penentang) pidana mati. Kelompok retensionis (setuju / pengamat) pidana mati pertimbangannya berbagai hal, diantaranya seperti sebagai upaya penanggulangan kejahatan berskala berat (general prevention), upaya menakut-nakuti calon dader untuk berbuat (daad) kejahatan yang beresiko tinggi terhadap orang lain sebagai korbannya (victim). Atau sebagai alasan sosio - yuridis - ekonomis politik terhadap kejahatan tertentu yang bersifat khusus dan sangat luar biasa seperti terorisme, narkotika, korupsi, kekerasan terhadap kaum rentan seperti anak, wanita dan usia lanjut, terlebih lagi kejahatan kemanusiaan berat (crimes against humanity).

Sehingga penjatuhan pidana mati tetap merupakan pertentangan antar dua kelompok yang pro dan kontra tadi, yang masing-masing mengeluarkan argumen justifikasi / alasan pembenar masing-masing. Sudut pandang masing-masing itu sulit mendapatkan titik temu, karena masing-masing pula mengandung misi dan tujuan yang semuanya hampir semua benar menurut versi masingmasing, antara tuntutan hukum guna kepentingan penegakan hukum berkeadilan dan berkepastian, di lain pihak guna perlindungan akan nyawa manusia yang tidak dapat diciptakan oleh manusia.

Berorientasi dari fenomena diatas, secara factual pidana mati tetap melahirkan problematis secara sosio - yuridis - politis seperti : 
1. Bagaimana konsepsi dan aplikasi pidana mati dalam peradilan pidana di Indonesia?

2. Apa yang menjadi justifikasi pembenar bagi pembentuk undang - undang dan hakim untuk menjatuhkan sanksi pidana mati dalam peradilan pidana di Indonesia?

Originalitas penelitian ini yaitu pertama dari jurnal kajian ilmu hukum dan syariah yaitu berjudul Polemik tentang Hukuman Mati Dalam Perundang-Undangan Nasional (Tinjauan Hukum Pidana Islam) oleh Mahammad Tahmid Nur, kedua dari jurnal magister ilmu hukum Universitas Syiah Kuala berjudul Pidana Mati Dalam Perspektif Peradilan Di Indonesia oleh Muzakkir, Faisal A. Rani, Dahlan Ali. Dari penelitian-penelitian sebelumnya yang menjadi perbedaan dari artikel ini adalah menekan pada dasar konsepsi penjatuhan pidana mati dan aplikasi pada sistem peradilan di Indonesia.

Tujuan dari penelitian ini adalah untuk mengkaji bagaimana konsepsi dan aplikasi pidana mati di Indonesia dan untuk menganalisis justifikasi pembenar dijatuhkannya sanksi pidana mati dalam peradilan pidana di Indonesia.

\section{METODELOGI PENELITIAN}

\subsection{Jenis Penelitian}

Penelitian ini tergolong kedalam jenis penelitian hukum normatif atau penelitian hukum kepustakaan, karena penelitian hukum ini dilakukan dengan cara meneliti bahan kepustakaan (library research) yang terdiri dari bahan hukum primer dan ditunjang oleh bahan hukum sekunder.

Menurut Soerjono Soekanto dan Sri Mamudji, penelitian hukum normatif atau kepustakaan tersebut mencakup :

1. Penelitian terhadap asas-asas hukum.

2. Penelitian terhadap sistematik hukum.

3. Penelitian terhadap taraf sinkronisasi vertikal dan horizontal.

4. Perbandingan hukum.

5. Sejarah hukum. ${ }^{3}$

Sehubungan dengan klasifikasi tersebut diatas maka penelitian hukum normatif menyangkut penelitian taraf sinkronisasi vertikal atas disharmonisasi norma yang ada antara KUHP dan beberapa undang-undang tindak pidana khusus dengan falsafah ideologi Pancasila.

\subsection{Metode Pendekatan}

Sesuai dengan karakteristik dan sifat penelitian kepustakaan, maka dalam penelitian ini akan memakai beberapa metode pendekatan, diantaranya :

- $\quad$ The Statue Approach pendekatan perundang-undangan.

- $\quad$ The Analitical and Conseptual

3 Soerjono Soekanto dan Sri Mamudji, 2001, Penelitian Hukum Normatif, Jakarta: PT. Raja Grafindo Persada, hlm. 14. 
Approach (pendekatan analisis konsep hukum).

- The Comparative Approach atau Pendekatan Perbandingan.

\subsection{Sumber Bahan Hukum}

Penelitian hukum jenis normatif, maka jenis bahan hukum yang lazim dipergunakan adalah :

a. Bahan-bahan Hukum Primer.

b. Bahan-bahan hukum sekunder.

c. Bahan-bahan hukum tersier. ${ }^{4}$

Sehubungan dengan penelitian hukum normatif ini maka memakai sumber bahan hukum dari :

1. Bahan Hukum primer, seperti: KUHP, UU Terorisme, UU Narkotika, UU Psikotropika dan UU Pengadilan HAM

2. Bahan hukum sekunder, yakni memberikan penjelasan mengenai bahan hukum primer.

3. Bahan hukum tersier, menyangkut seperti kamus atau ensiklopedi, jurnal, majalah, dan internet

\subsection{Metode Pengumpulan Bahan Hukum}

Penelitianiniuntukpengumpulan bahan hukum memakai metode sistematis, yakni berupa pengumpulan bahan peraturan perundang-undangan.

4 Ronny Hamijoyo Soemantri, 1998, Metode Penelitian Hukum dan Jurimetri, Jakarta: Ghalia Indonesia, hlm.11-12

\subsection{Teknik Analisis Bahan Hukum}

Menggunakan teknis analitis seperti :

- $\quad$ Teknik deskripsi

- Teknik interpretasi

- $\quad$ Teknik evaluasi

- $\quad$ Teknik argumentasi

- $\quad$ Teknik sistematisasi

- $\quad$ Metode konstruksi hukum

\section{HASIL DAN PEMBAHASAN}

Peneliti disini hanya

menampilkan hasil penelitian berupa analisis dari kajian secara deskriptif normatif. Melalui hasil kajian analisis atas masalah yang disajikan. Ada dua masalah pertama menyangkut analisis atas konsep dan aplikasi pidana mati dalam peradilan pidana Indonesia yang masih tetap dicanangkan dalam perundang-undangan pidana di Indonesia. Serta aplikasinya masih diberlakukan pidana mati tersebut terhadap beberapa tindak pidana tertentu seperti terorisme, narkotika, psikotropika dan pembunuhan berencana dengan kualifikasi khusus. Serta masalah kedua menyangkut dasar pembenar (justifikasi) pembentuk undang-undang maupun hakim untuk mencanangkan dan memutus dengan pidana mati berdasarkan pertimbangan bahwa suatu tindak pidana dijatuhi pidana mati terdakwa nya karena jenis tindak pidana yang dilakukan tergolong tidak pidana yang luar biasa (extra ordinary crime) dan sangat merugikan korbannya, serta pelaku 
sulit untuk dibina dan direhabilitasi kelakuannya, sehingga layak untuk diberi sanksi setimpal dengan pidana mati tersebut.

\subsection{Tindak Pidana Yang Diancam Pidana Mati Dalam Hukum Positif (Ius Constitutum) Indonesia}

\subsubsection{Ancaman Pidana Mati Dalam} KUHP

Kebijakan formulatif yang digunakan oleh pembuat undangundang dalam menentukan perbuatanperbuatan (tindak pidana) mana yang diancam dengan pidana mati menggunakan pendekatan selektif kondisional. Selektif maksudnya tidak terhadap semua tindak pidana diancam dengan sanksi pidana mati, akan tetapi terbatas terhadaptindakpidana tertentu, yang oleh pembuat undang-undang dipandang sebagai tindak pidana yang serius. Salah satu contoh konkrit dalam KUHP misalnya, pembunuhan yang diancam dengan pidana mati hanyalah terhadap tindak pidana pembunuhan yang direncanakan (Pasal 340 KUHP), sedangkan pembunuhan yang dilakukan tanpa perencanaan terlebih dahulu / pembunuhan biasa (Pasal 338 KUHP) tidak diancam dengan pidana mati. Berpijak dari kebijakan tersebut maka tindak pidana dalam KUHP yang diancam dengan pidana mati terbatas antara lain:

1. Pasal 104 KUHP (Makar terhadap Presiden dan Wakil Presiden);
2. Pasal 111 ayat (2) KUHP (Membujuk negara asing untuk bermusuhan atau berperang, jika permusuhan itu dilakukan atau jadi perang);

3. Pasal 124 ayat (3) (Membantu musuh waktu perang, Menyebabkan atau memudahkan atau menganjurkan huru-hara di kalangan angkatan perang);

4. Pasal 140 ayat (3) KUHP (Makar terhadap Raja atau Kepala Negara, Kepala Negara-negara sahabat yang direncanakan dan berakibat maut);

5. Pasal 340 KUHP (Pembunuhan berencana);

6. Pasal 365 ayat (4) KUHP (Pencurian dengan kekerasan yang mengakibatkan luka beratatau mati);

7. Pasal 444 KUHP (Pembajakan di laut, di pesisir, dan di sungai yang mengakibatkan kematian);

8. Pasal $479 \mathrm{k}$ ayat (2) KUHP (Pembajakan pesawat udara);

9. Pasal 479 o ayat (2) KUHP (Melakukan perbuatan kekerasan dalam pesawat, apabila mengakibatkan hancurnya pesawat atau matinya orang).

\subsubsection{Ancaman Pidana Mati Dalam Undang - Undang Tindak Pidana Khusus}

Perkembanganilmupengetahuan danteknologidiikutioleh tren kejahatan dengan memanfaatkan modus operandi kemajuan teknologi seperti bidang 
informasi teknologi dan komunikasi sehingga kejahatan sulit untuk dilacak dan dibuktikan. Beberapa jenis tindak pidana yang belum dan tidak diatur dalam KUHP, sehingga memunculkan tindak pidana khusus yang tergolong pula sebagai bentuk kejahatan luar biasa (extra ordinary crimes).

Karena sifat dan akibat yang ditimbulkan dari jenis tindak pidana tergolong khusus dan ekseptional ini memiliki jaringan luas, sangat merugikan masyarakat luas, dilakukan secara terorganisir, dipandang sebagai musuh umat manusia, korbannya tanpa membedakan laki-perempuan berdosa atau tidak dan tergolong sebagai kejahatan kemanusiaan berat, adalah sangat tepat dan pantas pelakunya untuk dijatuhkan pidana mati.

Adapun beberapa jenis tindak pidana tergolong sebagai tindak pidana khusus (diluar KUHP) yang telah dikodifikasi dalam legislasi pidana lex spesialis dengan pencantuman pidana mati dalam rumusan delik nya pada ius constitutum dan ius operatum diantaranya sebagai berikut :

a. Undang - Undang Nomor 31 Tahun 1999 yang telah diubah dengan Undang - Undang Nomor 20 Tahun 2001 tentang Pemberantasan Tindak Pidana Korupsi, dalam Pasal 2 ayat (2)nya mencanangkan pidana mati.

Tersurat : “... dalam keadaan tertentu, pidana mati dapat dijatuhkan". (Maksudnya adalah bahwa bagi terdakwa tindak pidana korupsi pelakunya dapat dipidana mati).

b. Undang - Undang Nomor 15 Tahun 2003 tentang Pemberantasan Tindak Pidana Terorisme, diatur dalam Pasal 6 bahwa pelaku tindak pidana terorisme dapat dipidana mati.

c. Undang - Undang Nomor 5 Tahun 1997 tentang Psikotropika dalam Pasal 59 ayat (2) dinyatakan, apabila pelaku melakukan secara terorganisir maka ia dapat dipidana mati

d. Undang - Undang No. 35 Tahun 2009 tentang Narkotika, dalam Pasal 113 ayat (2), Pasal 114 ayat (2), Pasal 116 ayat (2), Pasal 118 ayat (2), Pasal 119 ayat (2) dan Pasal 121 ayat (2), terhadap perbuatan pelaku yang tercantum dalam pasal-pasal tadi sebagai rumusan delik dapat dipidana mati.

e. Undang - Undang Nomor 26 Tahun 2000 tentang Pengadilan Hak Asasi Manusia (HAM) bagi pelaku genosida dan kejahatan kemanusiaan berat (crimes against humanity) pelakunya dapat dipidana mati (Pasal 36 dan 37)

\subsubsection{Ancaman Pidana Mati Dalam} Konsep /RUU KUHP

Dalam konsepsi KUHP, pidana pada hakikatnya hanya merupakan salah satu alat untuk mencapai tujuan. Bertitik tolak dari pandangan yang demikian maka pertama-tama pembuat Konsep KUHP mencantumkan 
perumusan tentang tujuan pemidanaan (Pasal 54 Konsep KUHP 2012). Dalam mengidentifikasi tujuan pemidanaan, Konsep bertitik tolak dari keseimbangan dua sasaran pokok, yaitu "perlindungan masyarakat" dan "perlindungan / pembinaan individu pelaku tindak pidana.

Bertolak dari keseimbangan dua sasaran pokok itu, maka syarat pemidanaan menurut Konsep juga bertitik tolak dari keseimbangan monodualistik antara kepentingan masyarakat dan kepentingan individu, antara faktor subjektif dan faktor objektif. Oleh karena itu syarat pemidanaan juga bertolak dari dua pilar yang sangat fundamental dalam hukum pidana, yaitu "asas legalitas" (merupakan asas kemasyarakatan) dan "asas kesalahan / asas culpabilitas (merupakan asas kemanusiaan). Dengan perkataan lain, pokok pikiran mengenai pemidanaan berhubungan erat dengan prinsip mengenai tindak pidana dan pertanggung jawaban pidana.

Dilihat dari pokok pemikiran yang lebih menitikberatkan pada perlindungan kepentingan masyarakat, maka wajar Konsep masih tetap mempertahankan jenis-jenis sanksi pidana yang berat, seperti sanksi pidana seumur hidup dan pidana mati. Meskipun demikian Menurut Konsep KUHP sanksi pidana mati bukan merupakan salah satu sanksi pidana pokok dalam stelsel sanksi pidana, seperti yang berlaku sekarang ini.
Sanksi pidana mati dikeluarkan dari sanksi pidana pokok, dan ditempatkan tersendiri sebagai jenis sanksi pidana yang bersifat khusus atau eksepsional (Pasal 59).

Pertimbangan utama digesernya kedudukan pidana mati itu didasarkan pada pemikiran, bahwa dilihat dari tujuan pemidanaan dan tujuan diadakan/digunakannya hukum pidana (sebagai salah satu sarana "kebijakan kriminal" dan "kebijakan sosial" pidana mati memang bukanlah sarana yang utama (primum remedium) untuk mengatur, menertibkan, dan memperbaiki masyarakat. Pidana mati hanya merupakan sarana pengecualian dan bersifat subsider, artinya apabila sarana lain tidak memadai baru dipakai pidana mati. Menurut Barda Nawai Arief pemikiran demikian dapat diidentikan enggan sarana amputasi atau operasi di bidang kedokteran yang pada hakikatnya juga bukan sarana / obat yang utama, tetapi hanya merupakan upaya perkecualian sebagai sarana / obat terakhir (ultimum remedium). ${ }^{5}$

Patut pula dikemukakan, bahwa walaupun dipertahankannya pidana mati terutama didasarkan pada upaya perlindungan masyarakat (jadi lebih menitikberatkan atau berorientasi pada kepentingan masyarakat, namun dalam penerapannya diharapkan bersifat selektif, hati-hati, dan berorientasi juga pada perlindungan / kepentingan individu (pelaku tindak pidana). Oleh

5 Barda Nawawi Arief, 1984, Teori-Teori dan Kebijakan Pidana, Alumni, Bandung, hlm. 2 
karena itu dalam konsep ada ketentuan mengenai penundaan pelaksanaan pidana mati atau pidana mati bersyarat dengan masa percobaan selama 10 tahun. Ketentuan tersebut dituangkan dalam konsep tahun 2016. Pidana mati ditempatkan sebagai pidana yang bersifat khusus (eksepsional), dan dimungkinkan adanya penundaan pelaksanaan pidana mati (pidana mati bersyarat). Hal ini sesuai dengan usulan Australia dalam Kongres PBB ke VII mengenai Prevention of Crime and Treatment of Offenders. Australia sebagai negara abolitionis (menolak / menghapus pidana mati) menghimbau kepada negara - negara yang belum menghapuskan pidana mati, untuk mempertimbangkan kemungkinan pengadaan dalam kerangka perundang-undangan nasionalnya, suatu moratorium (penundaan) dalam pelaksanaannya sekurang-kurangnya selama 3 tahun, atau dengan menciptakan kondisi-kondisi lain dalam mana hukum pidana mati tidak diperlukan dan tidak dilaksanakan.

Terlepas masih adanya pro dan kontra terhadap pidana mati, penulis secara pribadi berpendapat dalam era globalisasi di mana perkembangan teknologi dan informasi berkembang sangat pesat, telah membawa pola hubungan yang bersifat kompleks termasuk semakin berkembang kejahatan dengan dimensi yang sangat luas, sehingga tidak jarang membahayakan integritas sosial, maka untuk menjaga keutuhan integritas kehidupan manusia itu sendiri pidana mati masih sangat diperlukan

Sekalipun demikian pidana mati hendaknya digunakan dengan memperhatikan prinsip-prinsip subsideritas, ultimum remidium (obat terakhir), bersifat ekspesional dan memperhatikan perasaan keadilan masyarakat serta diterapkan berdasarkan prinsip kehati-hatian, terhadap bentuk - bentuk kejahatan sangat luar biasa (extra ordinary crimes)

\subsection{Retensionis dan Abolisionis Pidana Mati Dengan Penegakan Hukum}

\subsubsection{Klasifikasi dan Kriteria Suatu} Tindak Pidana Tergolong Sebagai Kejahatan Luar Biasa (Extra Ordinary Crimes)

Berbagai pendapat para ahli menyatakan bahwa dewasa ini sebagai perkembangan kejahatan model baru seiring dengan kemajuan ilmu pengetahuan dan teknologi komunikasi dan informasi canggih berdampak langsung pada modus operandi kejahatan yang menyertainya. Kejahatan inkonvensional dimaksud seperti tindak pidana korupsi, terorisme, pencucian uang, narkotika, kejahatan penghilangan nyawa orang dan modusnya. Sehingga pakar hukum seperti N. Serikat Putra Jaya, Abdul Wahid, H. Suharto, Abdul Latif, Dwi Hendro Sunarko dan para ahli lainnya hampir sama memberi ciri-ciri atau karakteristik dari suatu kejahatan 
model dan modus baru seperti tertera diatas, sehingga menampakkan anasir dan unsur - unsur seperti :

1. Kejahatan luar biasa (extra ordinary crime)

2. Kejahatan kemanusiaan berat (crimes against humanity)

3. Kejahatan lintas negara (transational crimes)

4. Kejahatan terorganisasi (organized crimes)

5. Kejahatan dilakukan dengan kekerasan (violence crimes)

6. Kejahatan dengan bentuk beragam (varied crimes)

7. Kejahatan internasional (international crimes)

8. Kejahatan terselubung (hidden crimes)

9. Kejahatan sebagai musuh seluruh umat manusia (hostes humanis generis)

Tampak bahwa tindak - tindak pidana atas kejahatan dengan ciri dan karakter seperti tersebut diatas bahwa perspektif penegakan hukumannya memerlukan penanganan serius dan terpadu. Upaya penegakan hukumnya mulai dari usaha preemptive, preventif dan represif. Pencegahan sejak dini berupa penanggulangan akan bentuk kejahatan extra ordinary crimes tersebut merupakan langkah awal yang harus dilakukan pencegahan berupa tindakan preemptive dan preventif. Baru kalau tidak berhasil dengan upaya penanggulangan barulah dilakukan cara-cara represif. Sebagaimana tagline mencegah lebih baik dengan pengobatan, juga sesuai dengan asas dalam hukum pidana ultimum remedium tersebut.

Kejahatan luar biasa (extra ordinary crimes) tentu sulit dihadapi dengan cara - cara biasa, tentunya memerlukan cara luar biasa pula (extra ordinary power / extra ordinary effort), yang dibutuhkan pula extra legal instrument, berupa politik hukum pidana (politik kriminal) yang bernuansa progresif, discretionary power (tindakan diskresi), bila diperlukan dalam penegakan hukumnya dipakai / diterapkannya penyimpangan-penyimpangan khusus dari ketentuan umum (general) dari substansi hukum pidana materiil maupun hukum acara pidana (hukum pidana formil) yang lexspesialist - temporer, namun tetap menjunjung tinggi due process of law.

Perlu diterapkannya hukum penyimpangan dalam proses peradilan pidana. Karena dalam proses atau mekanisme peradilan menghadapi tindak pidana luar biasa aspek pembuktiannya sangat sulit. Modus operandi pelakunya canggih, jaringan mereka luas serta sangat rahasia dan melibatkan jaringan terorganisir seperti dunia maya cyber space. Untuk mendeteksi dan mengejar pelakunya sulit bagi pelaku-pelaku kejahatan dalam extra ordinary crimes tersebut layak untuk dipidana mati.

Kelompok

retensionis

(mempertahankan) diterapkannya pidana pencabut nyawa ini lebih 
mengedepankan

perlindungan

masyarakat secara luas (general

prevention), dari masif nya korban yang tidak berdosa sebagai ulah para penjahat yang tanpa memandang korbannya.

\subsubsection{Negara - Negara Yang Pro dan Kontra Pidana Mati \\ 3.2.2.1.Negara - Negara Yang Masih (Pro) Mempertahankan \\ Pidana Mati (Kelompok Negara Retensionis)}

Berikut gambaran singkat beberapa Negara yang masih menerapkan pidana mati beserta jenis perbuatan dan cara pelaksanaannya :

\begin{tabular}{|c|c|c|c|}
\hline No & Negara & $\begin{array}{c}\text { Jenis Perbuatan / Kualifikasi Tindak } \\
\text { Pidana / Delik }\end{array}$ & Jenis Pelaksanaan \\
\hline 1 & CHINA & $\begin{array}{l}\text { Terorisme, peredaran obat terlarang, } \\
\text { memproduksi atau mendistribusikan barang- } \\
\text { barang beracun dan berbahaya, Perdagangan } \\
\text { seks, Penipuan kartu kredit. (ada } 68 \text { jenis } \\
\text { kejahatan) }\end{array}$ & Suntik mati, Tembak \\
\hline 2 & AMERIKA SERIKAT & Pembunuhan, Spionase, dan Pengkhianatan & Sengatan Listrik \\
\hline 3 & ARAB SAUDI & $\begin{array}{l}\text { Pembunuhan, pemerkosaan, perampokan, } \\
\text { penggunaan narkoba, pemurtadan, Perzinahan }\end{array}$ & $\begin{array}{l}\text { Pemenggalan kepala, Rajam } \\
\text { (Perzinaan) (didepan Umum) }\end{array}$ \\
\hline 4 & IRAN & $\begin{array}{l}\text { Pembunuhan, penggunaan perdagangan } \\
\text { narkoba, paedofilia, homoseksualitas, } \\
\text { spionase. }\end{array}$ & Digantung, Rajam \\
\hline 5 & KOREA UTARA & $\begin{array}{l}\text { Pembunuhan, pencurian, spionase, pembelotan, } \\
\text { pembangkangan politik, pengkhianatan, } \\
\text { membuat media yang tidak disetujui } \\
\text { pemerintah. }\end{array}$ & Ditembak \\
\hline 6 & BURMA & $\begin{array}{l}\text { Menentang pemerintahan secara sepihak } \\
\text { (oposisi), pembunuhan, pemerkosaan. }\end{array}$ & \\
\hline 7 & PAKISTAN & Pembunuhan, penghujatan, perzinaan & Digantung, Dirajam Perzinaan \\
\hline 8 & SYIRIA & $\begin{array}{l}\text { Pengkhianatan, pembunuhan, tindakan } \\
\text { politik terhadap pemerintah, perampokan, } \\
\text { pemerkosaan, oposisi politik. }\end{array}$ & $\begin{array}{l}\text { Digantung, ditembak (didepan } \\
\text { publik) }\end{array}$ \\
\hline 9 & YAMAN & $\begin{array}{l}\text { Perzinaan, murtad, perdagangan narkoba, } \\
\text { pemerkosaan, pembunuhan }\end{array}$ & $\begin{array}{l}\text { Cambuk, rajam (didepan } \\
\text { publik) }\end{array}$ \\
\hline 10 & LIBYA & $\begin{array}{l}\text { Pengkhianatan, perencanaan pembunuhan, } \\
\text { keputusan pemerintah }\end{array}$ & \\
\hline 11 & INDONESIA & $\begin{array}{l}\text { Korupsi, terorisme, narkotika, psikotropika, } \\
\text { pembunuhan berencana dan pelanggaran HAM } \\
\text { berat }\end{array}$ & Ditembak sampai mati \\
\hline
\end{tabular}

*) Dihimpun dari berbagai sumber 
Pakar hukum pidana Mardjono Reksodiputro menyatakan bahwa RUU KUHP masih mengadopsi hukuman mati. Menurutnya pidana mati masih diperlukan tetapi bukan pada pidana pokoknya. la harus menjadi pidana khusus yang diterapkan secara hatihati, selektif, dikhususkan pada kasuskasus berbahaya dan harus ditetapkan secara bulat oleh majelis hakim. RUU KUHP juga menerapkan apa yang dikenal dengan pidana mati percobaan atau sering disebut alternatif, mulamula dijatuhi pidana sepuluh tahun. Kalau dalam sepuluh tahun si terpidana, menunjukkan perbuatan terpuji, maka pidana mati diubah menjadi pidana seumur hidup atau penjara paling lama 20 tahun, jadi semacam pemberlakuan kedaluwarsa.

Selama ini hukuman mati dalam KUHP tidak ada batas daluwarsa nya. Sehingga ada kemungkinan seorang terpidana mati tidak kunjung dieksekusi hingga sepuluh tahun lebih. Kecenderungan dalam melaksanakan eksekusi kelihatan pemerintah masih ragu-ragu sehingga nasib terpidana terkatung-katung, tidak memberikan kepastian hukum. Hal demikian pengaturan upaya hukum peninjauan kembali dan grasi tidak jelas mengatur.

Dalam Rancangan KUHP 2016, pemerintah kembali mendorong pemberlakukan pidana mati, Pasal 66 yang menyatakan pidana mati merupakan pidana pokok yang bersifat khusus dan selalu diancamkan secara alternative. Ini berarti putusan pidana dan tindakan yang telah memperoleh kekuatan hukum tetap, masih dapat dilakukan perubahan atau penyesuaian dengan mengingat perkembangan narapidana dan tujuan pemidanaan. Bahkan Pasal 89 Rancangan KUHP dinyatakan pelaksanaan pidana mati dapat ditunda dengan masa percobaan 10(sepuluh)tahun jika : a. reaksi masyarakat terhadap terpidana tidak terlalu besar; b. terpidana menunjukkan rasa menyesal dan ada harapan untuk diperbaiki; c. kedudukan terpidana dalam penyertaan tindak pidana tidak terlalu penting; dan d. ada alasan yang meringankan. Jika terpidana semasa percobaan menunjukkan sikap dan perbuatan yang terpuji maka pidana mati dapat diubah menjadi pidana seumur hidup atau pidana penjara paling lama 20 (dua puluh) tahun melalui Keputusan Menteri yang menyelenggarakan; pemerintahan di bidang hukum dan hak asasi manusia. Namun jika terpidana selama masa percobaan sebagaimana dimaksud dalam ayat (1) tidak menunjukkan sikap dan perbuatan yang terpuji serta tidak ada harapan untuk diperbaiki maka pidana mati dapat dilaksanakan atas perintah Jaksa Agung.

Maka dapat di inventarisasi bahwa sampai saat ini negara-negara yang masih menerapkan pidana mati diantaranya adalah: Afghanistan, Bahrain, Bangladesh, Belarus, Botswana Chad, China, Cuba, Democratic Republic of the Congo, 
Egypt, Equatorial Guinea, Ethiopia, Gambia, India, Indonesia, Iran, Iraq, Japan, Jordan, Kuwait, Lebanon, Libya, Malaysia, Nigeria, North Korea, Oman, Pakistan, Palestinian national Authorit Authority, Qatar, Saint Kitts and Nevis, Saudi Arabia, Singapore, Somalia, South Sudan, Sudan, Syria, Taiwan, Thailand, Uganda, United Arab Emirates, United States America, Vietnam, Yemen and Zimbabwe.

\subsubsection{Kelompok Negara-Negara} Yang Tidak Setuju Akan Penerapan Hukuman Mati (Kelompok Penentang / Abolisionis)

Di lain pihak belahan dunia, ada sebanyak 84 negara turut menandatangani protokol opsional kedua kovenan internasional, tentang hak-hak sipil dan politik, yang bertujuan untuk menghapus hukuman mati di New York, 15 Desember 1989 silam.

Sebagaimana di lansir dari treaties.un.org, Jumat 13 Maret 2015, protokol tersebut telah didaftarkan sejak 11 Juli 1991, dengan Nomor. 14668 dan telah dicetak dalam Bahasa Arab, China, Inggris, Perancis, Rusia dan Spanyol.

Selain itu, peraturan internasional tersebut juga terbuka untuk ditandatangani di Markas Besar PBB di New York oleh semua negara yang telah menandatangani Kovenan Internasional tentang Hak Sipil dan Politik.
Berikut negara-negara yang telah menandatangani hukum internasional, perihal pidana cabut nyawa sekaligus diterapkan di peraturan domestik negara peserta :

\begin{tabular}{|c|c|c|c|}
\hline No & $\begin{array}{l}\text { Nama } \\
\text { Negara }\end{array}$ & $\begin{array}{l}\text { Perjanjian } \\
\text { Saat Mulai } \\
\text { Ikut Setuju }\end{array}$ & $\begin{array}{c}\text { Waktu } \\
\text { Meratifikasi }\end{array}$ \\
\hline 1. & Albania & 17 Okt 2007 & Belum \\
\hline 2. & Andorna & 5 Ags 2002 & 2 Sep 2006 \\
\hline 3. & Angola & 24 Sep 2013 & Belum \\
\hline 4. & Argentina & 20 Des 2006 & 2 Sep 2008 \\
\hline 5. & Australia & 2 Okt 1990 & Belum \\
\hline 6. & Austria & 8 Apr 1991 & 2 Mar 1993 \\
\hline 7. & Azerbaijan & 22 Jan 1999 & Belum \\
\hline 8. & Belgia & 12 Juli 1990 & 8 Des 1998 \\
\hline 9. & Benin & 5 Juli 2012 & Belum \\
\hline 10. & Bolivia & 12 Juli 2013 & Belum \\
\hline 11. & $\begin{array}{l}\text { Bos }{ }^{-1} \text { a } \\
\text { Herzego- } \\
\text { vina }\end{array}$ & 7 Sep 2000 & 16 Mar 2001 \\
\hline 12. & Brazil & 25 Sep 2009 & Belum \\
\hline 13. & Bulgaria & 11 Mar 1999 & 10 Ags 1999 \\
\hline 14. & Cape Verde & 19 Mei 2000 & Belum \\
\hline 15. & Canada & 25 Nop 2009 & Belum \\
\hline 16. & Cili & 15 Nop 2001 & 26 Sep 2008 \\
\hline 17. & Columbia & 5 Ags 1997 & Belum \\
\hline 18. & Cesta Rica & 14 Febi 1990 & 5 Juni 1998 \\
\hline 19. & Kroasia & 12 Okt 1995 & Belum \\
\hline 20. & Siprus & 10 Sep 1999 & Belum \\
\hline 21. & $\begin{array}{l}\text { Republik } \\
\text { Ceko }\end{array}$ & 15 Juni 2004 & Belum \\
\hline 22 & Denmark & 13 Feb 1990 & 24 Feb 1994 \\
\hline 23. & Djibouti & 5 Nop 2002 & Belum \\
\hline 24. & Ekuador & 23 Feb 1993 & Belum \\
\hline 25. & El salvador & 8 April 2014 & Belum \\
\hline 26. & Estonia & 30 Jan 2004 & Belum \\
\hline 27. & Finlandia & 13 Feb 1990 & 4 April 1991 \\
\hline 28. & Perancis & 2 Okt 2007 & Belum \\
\hline 29. & Gabon & 2 April 2014 & Belum \\
\hline 30. & Georgia & $\begin{array}{ll}22 & \text { Maret } \\
1999 & \\
\end{array}$ & Belum \\
\hline
\end{tabular}

Cataran urutan 31-84 negara-negara tersebut penulis tidak cantumkan (data selanjutnya ada pada penulis) 
3.3 Fungsi Hukum Pidana Dalam Penegakan Hukum Dengan System Penegakan Hukum Secara Terpadu (Integrated Criminal Justice System)

Fungsi hukum pidana secara teoretis telah terpatri melalui 2 (dua) buah asas utama (primum remidium) dan fungsi hukum pidana sebagai sarana atau alat/alat terukur dalam memerangi pelaku kejahatan. Dihadapkan sebagai pelaku tindak pidana dalam kualifikasi kejahatan luar biasa (extra ordinary crime) atau tergolong tindak pidana khusus maka pidana mati sebagai sanksi pidana terberat dalam straaf sort dan straaf maat hukum pidana adalah cocok dan layak serta tepat untuk diterapkan kepada pelakunya.

Asas ultimum remidium ${ }^{6}$ menjadi pijakan pihak sebagai dasar pembenar bagi jaksa dalam menuduh dan menuntut pelaku-pelaku kejahatan sangat luar biasa tersebut. Begitu pula bagi hakim dalam memutus, dengan sedikit menyampingkan aspek kemanusiaan namun mengedepankan kepentingan hukum dan kepentingan masyarakat luas dalam mencegah dan memerangi kejahatan bagi hakim memutuskan dengan pidana mati adalah mendapat justfikasi legal secara atributif bagi hukum dalam memidana mati pelaku/terdakwa kejahatan luar biasasangattersebardantersuratbanyak dalam perundang-undangan pidana

6 Sudikno Mertokusumo, 2006, Penemuan Hukum Sebuah Pengantar, Liberty, Yogyakarta,hlm.7
Indonesia. Kewenangan diskresi, serta impartialitas dan independensi hakim mendapat alasan pembenaran oleh esensi teori pembalasan (teori absolut) dalam pemidanaan pelaku kejahatan terlebih dader-nya berkualifikasi tindak pidana luar biasa.

Menurut analisis penulis penjatuhan pidana mati bagi pelaku kejahatan luar biasa adalah tepat dan setuju, bila pula dihadapkan dengan konsepsi dan pandangan ahli hukum pidana serta ilmuwan peradilan pidana Helbert L. Packer yang mengkonsepsi bahwa peran sanksi pidana tetap dibutuhkan sampai kapan pun, dalam pernyataannya menyatakan seperti berikut :

1. Sanksi pidana sangatlah diperlukan; kita tidak dapat hidup sekarang maupun di masa yang akan datang, tanpa pidana (The criminal sanction is indispensable; we could not, now or in the foreseeable future get along, without it).

2. Sanksi pidana merupakan alat sarana terbaik yang tersedia, yang kita miliki untuk menghadapi ancaman-ancaman dari bahaya (The criminal sanction is the best avaible device we have for dealing with gross \& immediate harms and threats from harms).

3. Sanksi pidana suatu ketika merupakan penjamin yang utama dari kebebasan manusia. Ia merupakan penjamin apabila digunakan secara hemat-cermat 
dan secara manusiawi, ia merupakan pengancam apabila digunakan secara sembarangan dan secara paksa (The criminal sanction is at once prime guarantor and prime thteatemer of human freedom, used providently and humanely, it is guarantor; used indiscriminatrly and it is corecvely threatener. ${ }^{7}$

Pentingnya Hukum Pidana, pidana dan Pemidanaan

1. Andrew Ash Worth A criminal law without sentencing would merely cel a declaratory system prounduncing people quilty without formal consequences following from that quilt." (Pemidanaan merupakan bagian terpenting dalam hukum pidana karena merupakan puncak dari seluruh proses pertanggungjawaban seseorang yang akan bersalah melakukan tindak Pidana). ${ }^{8}$

2. HL. Packer ada 3 hal prinsip dalam hukum pidana (the there basic problem of substance as opposed to procedure in criminal law) :

1. What conduct should cel designated as criminal? (tindakan apa yang bisa disebut sebagai tindak pidana).

7 Herbert. L. Packer, 1967, The Limits Of The Criminal Sanction, Stanford California University Pres, hlm : 344

8 Andrew Ash Worth, 1991, Principle of criminal law, Oxfoard, Clarendon press, hlm.72
2. What determination must cel made vefore a persom can cel ound to have committed a criminal of fences? (Apa kriteria sebagai penentu seseorang bisa disebut sebagai pelaku tindak pidana)?

3. What should cel dine with person who are found to have commited criminal affences? (Apa yang harus dilakukan terhadap pelaku dari suatu tindak pidana)? ${ }^{9}$

\section{KESIMPULAN}

1. Perspektif ius constitutum dan ius operatum dalam beberapa perundang-undangan Indonesia masih mencanangkan dan menerapkan ketentuan pidana mati sebagai jenis pidana (strafsort) pokok, seperti KUHP, UU No.31 Tahun 1990, UU No.20 Tahun 2001 tentang Pemberantasan Tindak Pidana Korupsi, UU No.26 Tahun 2000 tentang Peradilan HAM, UU No. 35 Tahun 2009 tentang Narkotika, UU No.5 tahun 1997 tentang Psikotropika dan UU No.15 tahun 2003 tentang Pemberantasan Terorisme Perspektif Insconstituendum dalam RUU-KUHP Nanonal tahun 2016 pidana mati masih dikonsepsi bahkan dikeluarkan dari penempatan pidana pokok,

9 Hl. Packer, Op Cit, P. 17 
namun diatur tersendiri dan bersyarat.

2. Sebagai dasar pembenar atau justifikasi secara teori keilmuan hukum bahwa pidana mati masih mungkin untuk dijatuhkan bagi pelaku tindak pidana yang tergolong luar biasa (extra ordinary crime / atau bahkan tergolongkejahatankemanusiaan berat (crimes against humanity) berdasarkan teori-teori diantaranya teori retributivisme atau proporsionalitas, teori ganjaran (deserts theory), teori resiprositas, teori pemidanaan absolut, teori keadilan (distributive) teori Hak Asasi Manusia (HAM) dan teori Utilitiariasnisme.

\section{DAFTAR PUSTAKA}

\section{Buku}

Andrew Ash Worth, 1991, Principle of Criminal Law, Oxford Claren don Press

Barda Nawawi, Arief, 1984, Teori - Teori dan Kebijakan Pidana, Alumni, Bandung

Djatmiko, Rachmad, 1962, Pidato Diesnatalis, Surakartam

Dokumen PBB, 1990, A/CONF.144/ C.2/L.7, Laporan Kongres PBB ke-8, Badan Pembinaan Hukum Nasional Departemen Kehakiman Republik Indonesia Hamzah, Andi dan A.Sumangelipu, 1984, Pidana Mati di Indonesia di Masa Lalu, Kini, dan Masa Depan, Galia Indonesia, Jakarta
Herbert L. Packer, 1967, The Limits of The Criminal Sanction, Stanford California University Press

Kaelan, 1991, Filsafat Pancasila, Fakultas Filsafat Universitas Gajah Mada, Jogjakarta

Marmosujono, Sukarton, 1989, Pidana Mati dalam Kaitannya dengan Dasar Falsafah Bangsa Indonesia (Pancasila), Surakarta

Muladi, 1990, Karakteristik Hukum Pidana Materiil Indonesia di Masa Datang, Pidato Pengukuhan Guru Besar Ilmu Hukum Pidana, Fakultas Hukum UNDIP

Muladi dan Barda Nawawi Arief, 1984, Teori-teori dan Kebijakan Pidana, Alumni, Bandung

Notonagoro, 1988, Pancasila Dasar Filsafat Negara, Bina Aksara, Jakarta

Ronny Hamijoyo Soemantri, 1998, Metode Penelitian Hukum dan Jurumetri, Ghalia Indonesia, Jakarta

Sahetapy, 1982, Suatu Studi Khusus Mengenai Ancaman Pidana Mati Terhadap Pembunuhan Berencana, CV. Rajawali, Jakarta

Soerjono Soekanto dan Sri Mamudji, 2001, Penelitian Hukum Normatif, PT. Raja Grafindo Persada, Jakarta

Sudikno Mertokusumo, 2006, Penemuan Hukum Sebuah Pengantar, Liberty, Yogyakarta 
Utrecht, 1960, Hukum Pidana I,

Pustaka Tinta Mas, Surabaya

\section{Undang-Undang}

KUHP (Kitab undang - Undang Hukum Pidana)

Undang-undang No.31 Tahun 1999 Jo

UU No.20 Tahun 2001 tentang

Pemberantasan Tindak Pidana

Korupsi

Undang-Undang No.35 Tahun 2009

Tentang Narkotika

Undang-undang No. 5 Tahun 1997

Tentang Psikotropika

Undang-undang No.15 Tahun 2003

Tentang Terorisme

Undang-undang No.26 Tahun 200

Tentang Pengadilan HAM

Konsep RUU-KUHP Nasional Tahun

2016. 